\title{
Teacher Emotional Intelligences: A Demographic Perspective of a Comparational Study of the Teachers at Public Senior High Schools at Tangerang, Banten, Indonesia
}

\author{
Supardi ${ }^{1}$ \\ ${ }^{1}$ Faculty of Teacher Training and Education, IAIN "SMH” Banten, Indonesia \\ Correspondence: Supardi, IAIN Sultan Maulana Hasanuddin Banten Jl. Jenderal Sudirmana No. 30 Serang \\ Banten, Indonesia. E-mail: supardi_ahalim@yahoo.com
}

Received: July 14, 2014 Accepted: August 21, 2014 Online Published: September 28, 2014

doi:10.5539/ies.v7n10p112

URL: http://dx.doi.org/10.5539/ies.v7n10p112

\begin{abstract}
The objective of this research is to compare teacher emotional intelligence based on their sex, levels of education and the length of their devotion. The conceptual framework of this research is the Goleman's Emotional Intelligence Theory. To collect data, Boyatzis' questionnaire instrument on the teacher emotional intelligence was employed. The instruments were sent to State Secondary High School Teachers in Tangerang city. The data were analysed using SPSS version 16.00. The inferential statistical method t-Test and one-way ANOVA were employed. The findings of this research show that there is a difference in the teacher emotional intelligence based on their sex, levels of education and the length of their devotion. The implication of this findings is that emotional intelligence may be improved by recognizing one's own emotion, managing emotion, recognizing others' emotion, building rapport, developing and maintaining emotional skills, doing religious activities and by practicing emotional and spiritual drills.
\end{abstract}

Keywords: emotional intelligence, self-awareness, self-management, social awareness, relation management

\section{Introduction}

Teachers should possess emotional intelligence to attain competencies needed as teachers. Stages of emotional intelligences an individual has prove to play more important roles than traditional cognitive competences in the success of managing one's various problems. Emotional intelligences deal with what is usually called as internal, deepest-self. The world of personal relation determines the degree of our feelings towards and our satisfaction with our success. In this case, the success means that one may express his/her feelings well, may live and work independently, may be rigid and may have self-confidence in expressing his/her feelings and belief. Holahan and Sears (1995) studying the successful women found that self-confidence at the beginning of doing a job contributes to their success.

With the skills of processing emotional intelligences, teachers may place themselves and possess some awareness among school members and community members of which such awareness are the demand of their social competences. Teachers possess self-awareness in order to be able to control their emotions and their performance which are personal competences they should have. Therefore, emotional intelligences may improve teachers' competences. Based on a demographic perspective of teacher emotional intelligences, there are some differences, but sometimes also similarities, in groups of sex, age, level of education and the length of devotion.

Aspects of emotional intelligences are those of teacher personal and social competences. But there are teachers with low emotional intelligences, for example, many teachers who often show their anger with their students. According to Mulyasa (2005), such anger is often caused by students with less competence in solving or answering problems, whereas, they have studies hard. Moreover, the anger marks their emotional instability and intelligence.

As a result, teachers often exceedingly give punishments to students, especially physical punishments as done by a teacher in Cilegon Banten, Indonesia, who hit his student because of improper behavior the student showed (Setiawan, 2000). The student did not show any respect and even railed at him although the teacher had given him answers for the national examination. The teacher was wrong in sending the answers of the national examination through SMS or pieces of papers. 
According to Muchtar and Priambodo (2003), sometimes, there are teachers who do not want to pay attention to inputs and suggestions, especially those from students. Whereas, the freedom and bravery of the students to express their ideas sincerely are very useful for teachers, although they are painful for teachers.

Parker (1990) found that teachers with negative emotions have troubles in building rapports with other teachers. It is due to low self-confidence, followed by isolating themselves from other teachers, being depressed, showing social problems, striving aggressively against others and making the teaching and learning processes in the classroom ineffective.

\section{Review of Related Literature}

\subsection{Emotional Intelligence}

A theoretical framework of emotional intelligence in this study is the Emotional Intelligence-based Achievement Theory developed by Goleman (2001) based on his writing with the title of Working with Emotional Intelligence in his book The Emotionally Intelligent Workplace. Goleman (2001) divides emotional intelligence into two parts namely self-intelligence and social intelligence. Self-intelligence covers the first part, self-awareness and self-management groups, and the second part, social intelligence consists of social awareness and relation

The emotional intelligence group, which had been developed by Goleman (2001), was then developed by Boyatzis, Goleman, and Rhee (2000) into four groups. The first group, self-awareness, includes: self-emotion awareness accuracy of, self-evaluation and self-belief. The second group, self-management covers: control of self-emotion, orientation to achievement, optimistic attitudes, sincerity, ability to self-adaptation and initiative. The third group, social awareness consists of empathy, orientation to service, and organization awareness. And the fourth group, relation management, includes: developing other people, inspired-leadership, pioneer to changes, conflict management, group influence and cooperation.

According to Boyatzis, Goleman, and Rhee (2000), the self-awareness group is a condition to a more effective self management group, and the self-awareness group contributes to the social awareness group for the social competence group. Self-awareness is a key to the awareness of personal strengths and weaknesses.

The self-management group with the subtheme of initiative tends to raise innovative ideas to respond a change in an organization (Amabile, 1988). The subtheme optimistic attitude, as Spencer and Spencer predicts (1993) is an important formula to the attainment since it can determine any beneficial responses or not, based on certain conditions or events. And the subtheme ability to self-adaptation according to Amabile (1998) is an aspect of the emotional intelligence that will justify to someone to feel comfortable although he is often in doubt and uncertain.

The social awareness group plays a main role in improving the service achievement that involves efforts to analyse subordinates' or clients' needs (L. Spencer \& S. Spencer, 1993). This social awareness provides an individual with ability to read situations objectively, and with assumptions to act effectively (Boyatzis, 1982).

The relation management group depends on the principles of self-management and social relations, where the principles of the emotional intelligence are the emotional intelligence in the self-awareness.

A win-win relation in a school organization (the head master, teachers, staffs and members of education committee, in general) will happen if the involved parties possess emotional intelligence that a sharp difference is not more than a seed that may results in failures in the organization they serve as general services or actors making the intelligence (Danim, 2003). The emotional intelligence the teachers possess may make teachers manage their emotions and emotions of others and may change negative emotions into positive ones.

The Goleman emotional intelligence theory (1998) has been by Boyatzis (2001) provided with questionnaires on Emotional Competence Inventory (ECI-2). This instrument is developed from the instrument on Working With Emotional Intelligence (Goleman, 1998) and Self Assessment Questionnaire (SAQ) (Boyatzis, 2001) and is a version which is often used to measure the emotional intelligence of professionals. And this instrument is appropriate for teachers since the the groups of professionals in the field of education should fulfill certain conditions among others pedagogical, personal, social and professional competences.

\subsection{A Demographic Perspective}

Perspective is from Latin word, per meaning through and spectra, looking at. Simply, the word perspective may be defined into looking at something in the forms of objects, ideologies, concepts, beliefs, and the like through certain media.

The word perspective according to the cognitive science is estimation in politics of contexts or references in ideologies considered as a legitimating based on codification, experiences, evaluation in building a coherent trust, 
paradigm comparation, comprehensive point of view and realities.

Demography according to Hauser and Duncan (1959) is a branch of science that studies numbers, territorial distribution, population composition, and their changes and causes of the changes. Meanwhile Bougue (1969) defines demography as a branch of science studying numbers statistically and mathematically, composition, population distribution, and their changes as a result of the components of population growth such as fertility, mortality, marriage, migration, and social mobility.

In demography, a population composition is known. His composition is based on age and sex, social aspects (levels of education, marriage) and on economical aspects (job and levels of incomes) (Rismawari, 2012; Indriyuli, 2011).

Therefore, this demographic perspective in this present research is a view on the reality of teacher emotional intelligence by paying attention to differences and similarities aspects of teacher emotional intelligence from sex, age, levels of education and the length of devotion as teachers.

\subsection{The Conceptual Framework of The Research}

Referring to the previous results of researches, a conceptual framework is developed by the researcher by using emotional intelligence variables and demographic perspective (see Figure 1).

\begin{tabular}{|l|l|l|l|}
\hline $\begin{array}{l}\text { Teacher Emotional Intelligence } \\
\text { 1. Self- management } \\
\text { 2. Self-awareness } \\
\text { 3. Social awareness } \\
\text { 4. Relation Management }\end{array}$ & $\begin{array}{l}\text { Demographic perspective } \\
\text { 1. Sex } \\
\text { 2. Age } \\
\text { 3. Levels of education } \\
\text { 4. Long of activity }\end{array}$
\end{tabular}

Figure 1. A conceptual framework of the research

The conceptual framework of this research is based an opinion that there are differences in emotional intelligences of men and women (Goleman, 1999; Don, 2009), of ages (Sala, 2002), Bar-On and Goleman (1998), of the length of devotions (Crick, 2002), Fernadez-Araoz (2001) and Boyatzis and Sala (2004).

\section{Method}

In this present research, the method used is quantitative because a quantitative study is appropriate for measuring variables dealing with a phenomenon without questioning why the variables exist or happen, Konting (1990). Another opinion that a quantitative method is most appropriately used since the focus of the research is to investigate the comparison of teacher emotional intelligences based on the sex, age, levels of education and the length of devotion.

Data in this research were collected using questionnaires. A questionnaire is a way to obtain answers for research questions (Kerlinger, 1993). And the questionnaires may cover a wide area and be easily made without the attendance of the researcher (Rubin \& Babbie, 2001).

The objective of this research is to compare teacher emotional intelligences based on sex, age, levels of education and length of devotion. So that, the inferential statistics employed were the t-test ad one-way ANOVA test. This research was made in ten sub-districts in Tangerang city: Tangerang, Cipondoh, Pinang, Ciledug, Karang Tengah, Larangan, Karawaci, Batu Ceper \& Benda.

The population is all teachers 600 persons working in state secondary high schools in Tangerang city, Banten province. All the population is taken as the sample. Gay and Airasin (2001) state that $10 \%$ is a minimum number of samples that may be used to represent a population.

In this research, a questionnaire coverings aspects discussed in the conceptual framework was used. The questionnaire on teacher emotional intelligence is the one made use of by Don (2007) and is a back-translation from the test of Emotional Competence Inventory (ECI-2) developed by Boyatzis (2001). This instrument from the working with emotional intelligence (Goleman, 1998) and self assessment questionnaire (SAQ) (Boyatzis, 1991) and the mostly used version to measure the emotional intelligence of professionals and executives in trade.

The test items of ECI-2 divide teacher emotional intelligences into four groups namely: 1) self-awareness that 
deals with awareness of self-emotion, proper self-evaluation and self-belief; 2) self management containing self-emotion control, sincerity, ability to self-adaptation, optimistic attitudes, orientation to attainment and initiative; 3) social awareness covering: empathy, orientation services, and organization awareness; 4) relation management that deals with developing other people, inspired-leadership, pioneers to changes, influences, conflict management, and group collaborative cooperation. The number of items of the emotional intelligence is 1) self awareness, (12); 2) self- management (24); 3) social awareness (12) and relation management (24).

Before the application, the validity and the reliability of the instrument were try-out. The instrument of the teacher emotional intelligence consists of four subthemes namely self-awareness, self-management, social awareness and relation management and the number of the items of the questionnaires is 73 .

In this research, the correlation between the items and the number of scores was used to measure the validity of the questionnaires and the Alpha-Cronbach index is used to measure the levels of reliability of the items and the subthemes in the instrument. The coefficient value at 0.3 (Pers, 1996) and the Alpha-Cronbach index, at 0.7 above (Pallant, 2001; Hair, 1998) are used to determine the level of the instrument validity and reliability, respectively. The analysis of the try-out for each subtheme and each items of the questionnaires are presented in Table 1.

Table 1. The Value of the correlation between the score of each item test and the number and index of Alpha-Cronbach for subthemes in teacher emotional intelligence

\begin{tabular}{llccc}
\hline No. & Aspects & $\begin{array}{c}\text { Number of } \\
\text { Items }\end{array}$ & $\begin{array}{c}\text { Correlation between the Items and the } \\
\text { Scores }\end{array}$ & $\begin{array}{c}\text { Alpha } \\
\text { Value }\end{array}$ \\
\hline 1 & Self-management & 24 & $0.341-0.597$ & 0.846 \\
2 & Self-awareness & 12 & $0.404-0.704$ & 0.782 \\
3 & Social awareness & 12 & $0.304-0.646$ & 0.830 \\
4 & Relation & 24 & $0.318-0.572$ & 0.715 \\
& management & & & 0.793 \\
\hline & Number/Average & 72 & $.342-629$ & \\
\hline
\end{tabular}

On the basis of the Table 1, there is a correlation between the score of each item and the number of the subthemes of self-management where the number of the items are 24. The value of the correlation is from 0.341 to 0.597 . The whole items had a correlation between an item and the number of the highest scores namely 0.25 (Nunally, 1978) and 0.3 (Pers, 1996), respectively. The Alpha-Cronbach reliability index for the subtheme of slef-management is also high, namely 0.846 . This shows that all the items in the self-management aspect have high validity and reliability and may be used in this present research (Sekaran, 1992; Konting, 1990). This analysis shows that each item in the sub-themes of self-management has high validity and reliability.

Table 1 shows the value of the correlation between the score of each item and the number of the scores of the subtheme of self-management. The value of the correlation between items and the number of scores are 0.404-0.704. The Alpha-Cronbach reliability index for the subtheme of self-awareness is also high, namely 0.782 . This shows that all items in the subtheme of self-awareness have high validity and reliability, so that they may be used in this research.

Table 1 also shows the value of the correlation between the score of each items and the number of scores of the subtheme of social awareness (12 items). The value of the correlation between items and the number of scores are $0.304-0.646$. The Alpha-Cronbach reliability index for the subtheme of social awareness is also high, namely 0.830 . This shows that all items in the subtheme of social awareness have high validity and reliability, so that they may be used in this research.

Table 1 also shows the value of the correlation between the score of each item and the number of scores of the subtheme of self-management (24 items). The value of the correlation between items and the number of scores are $0.318-0.572$. The Alpha-Cronbach reliability index for the subtheme of self-management is also high, namely 0.715 . This shows that all items in the subtheme of social awareness have high validity and reliability, so that thay may be used in this research. 


\section{Results and Discussion}

\subsection{Results}

\subsubsection{Differences in Sex-based Teacher Emotional Intelligence}

From the answers to the questionnaire on teacher emotional intelligence from 248 male and 352 female respondents, the differences in teacher emotional intelligence based on the sex are known. The summary of the results is presented at Table 2 .

From the table, the t-test of the sex-based teacher emotional intelligence shows that the difference $\mathrm{s}$ in sex-based teacher emotional intelligence at the limit of $\mathrm{p}<0.05$ as a whole is $\mathrm{t}=.004$; Sig. $=.035$. It may be concluded that there is a difference between the sex-based teacher emotional intelligence and the subthemes of self-awareness, self-management, social awareness and relation management.

Table 2. T-test on sex-based teacher emotional intelligence

\begin{tabular}{|c|c|c|c|c|c|}
\hline Source & $\mathrm{N}$ & Mean score & Standard of Deviation & t-value & Significance \\
\hline \multicolumn{6}{|c|}{ Self-awareness } \\
\hline Men & 248 & 84.92 & 6.41 & -.401 & .385 \\
\hline Women & 352 & 84.72 & 5.90 & & \\
\hline \multicolumn{6}{|c|}{ Self-management } \\
\hline Men & 248 & 45.46 & 4.51 & -.902 & .458 \\
\hline Women & 352 & 45.78 & 4.22 & & \\
\hline \multicolumn{6}{|c|}{ Social awareness } \\
\hline Men & 248 & 46.52 & 3.88 & .618 & .683 \\
\hline Women & 352 & 46.74 & 4.30 & & \\
\hline \multicolumn{6}{|c|}{ Relation management } \\
\hline Men & 248 & 92.25 & 92.25 & -.395 & .253 \\
\hline Women & 352 & 92.45 & 92.45 & & \\
\hline \multicolumn{6}{|c|}{ Whole Teacher Emotional Intelligence } \\
\hline Men & 248 & 276.52 & 16.85 & .004 & $.035^{*}$ \\
\hline Women & 352 & 276.53 & 14.86 & & \\
\hline
\end{tabular}

*Significance at limit $p<0.05$.

\subsubsection{Differences in Teacher Emotional Intelligence Based on Age}

The differences of the age-based teacher emotional intelligence are obtained from the questionnaires returned by the following groups of respondents and also their numbers: 42 respondents at the age group of 25 years of more, 111 respondents, 30 years of more; 138 respondents, 35 years or above; 149 respondents, 40 years of more; 59 respondents, 45 years of above; 48 respondents, 50 years of above; and 53 respondents, 55 years of more. The data were then analysed using the one-way ANOVA. The results, as shown in Table 2 above showed that the highest mean scores of the teacher emotional intelligence based on age are obtained from the age groups of 30 years of more (average $=28.07$ ), then followed by the age group of 50 years of more (279.08), of 40 years (277.61), 55 years of more (275.52), 35 years of more (276.09) and by the age group of 25 years of more (268.24). 
Table 3. Mean scores of the teacher emotional intelligence based on age

\begin{tabular}{llcc}
\hline Age Group & $\mathrm{N}$ & Average rate & Standard of Deviation \\
\hline 25 years of more & 42 & 268.24 & 16.42 \\
30 years of more & 111 & 280.07 & 15.09 \\
35 years of more & 138 & 276.09 & 16.63 \\
40 years of more & 149 & 277.61 & 15.14 \\
45 years of more & 59 & 277.95 & 15.84 \\
50 years of more & 48 & 279.08 & 13.22 \\
55 years of more & 53 & 276.52 & 15.70 \\
\hline
\end{tabular}

In Table 3 the results of the one-way ANOVA of the differences of the teacher emotional intelligence based on age show that there is a significant difference of the mean score of the teacher emotional intelligence based on age (F; 6: 1217.47) $=5.91 ; \operatorname{sig} .000)$.

Table 4. The results of the one-way ANOVA of the teacher emotional intelligence based on age

\begin{tabular}{lccccc}
\hline Source & Sum of Squares & Df & Mean Square & F & Sig. \\
\hline Between Groups & 7304.80 & 6 & 1217.47 & $5.91 .000^{*}$ \\
In Groups & 140400.87 & 593 & 236.76 & \\
Sum & 147705.67 & 599 & & \\
\hline
\end{tabular}

*Significant at limit $\mathrm{p}<0.05$.

**Significant at limit $\mathrm{p}<0.01$.

\subsubsection{Differences in Teacher Emotional Intelligence Based on the Level of Education}

To understand whether there is a difference in the teacher emotional intelligence based on the level of education, data were obtained from the answers of the questionnaires distributed from 549 teachers with degree certificates and 51 teachers with master certificates. The data were then analysed using independent $t$-test. The results are presented in Table 5.

Table 5. The results of the t-test of teacher emotional intelligence based on the level of education

\begin{tabular}{lccccc}
\hline Source & N & Mean Score & Standard of Deviation & T-Value & Significance \\
\hline Self-management & & & & & \\
Certificate S1 & 549 & 84.8998 & 6.06255 & 1.313 & .569 \\
Certificate S2 & 51 & 83.7255 & 6.60630 & & \\
\hline Relation management & & & & & \\
Certificate S1 & 549 & 45.5701 & 4.36529 & -.398 & .047 \\
Certificate S2 & 51 & 45.8235 & 4.12168 & & \\
\hline Social awareness & 549 & 46.6976 & 4.18020 & .958 & .037 \\
Certificate S1 & 51 & 46.1176 & 3.53071 & & \\
Certificate S2 & & & & & \\
\hline Self-awareness & 549 & 92.3424 & 6.56545 & -.296 & .970 \\
Certificate S1 & 51 & 92.6275 & 6.67521 & & \\
Certificate S2 & & & & & \\
\hline
\end{tabular}




\begin{tabular}{lccccc}
\hline Teacher Emotional Intelligence & & & & & \\
Certificate S1 & 549 & 276.6302 & 15.72331 & .547 & .040 \\
Certificate S2 & 51 & 275.3725 & 15.59097 & & \\
\hline
\end{tabular}

*Significant at limit $p<0.05$.

Table 6 presents the results of the t-test of the teacher emotional intelligence based on the level of education showing that there is no difference in the teacher emotional intelligence based on the level of education at limit of $\mathrm{p}<0.05$. There ir no difference in the teacher emotional intelligence at the subtheme of teacher self-awareness $(\mathrm{t}=1.313$; $\mathrm{Sig}=.569)$, and also in the subtheme of self-management $(\mathrm{t}=-.398$; Sig. $=-.647)$ but there is difference in the subtheme of social awareness $(t=.958$; Sig. $=.037$. $)$ and there is no difference in the subtheme of relation management $(\mathrm{t}=-.296$; Sig. $=.970)$. But as a whole there is difference in the teacher emotional intelligence $(\mathrm{t}=.547$; Sig. $=.040)$.

In conclusion, as a whole, there is a difference in the teacher emotional intelligence based on the level of education in the subtheme social awareness.

4.1.4 Differences in Teacher Emotional Intelligence Based on the Length of Devotion

To understand the difference in the teacher emotional intelligence based on the length of devotion, answers to the questionnaires distributed to the teachers are analysed. There are 55 teachers with the length of devotion of 1-5 years, 202 teachers, 6-10 yeas, 164 teachers, 11-15 years, 128 teacher, $16-20$ years, 51 teachers 21 or more. A one-way ANOVA was used to understand the difference in the teacher emotional intelligence based on the length of devotion. Table 8 shows that the highest mean scores are from the teachers' length of devotion of 6-10 years (the mean of 278.444), then followed by 11-16 years (278.44), 16020 years or more (278.43), 21 (371.53) and the lowest the length of devotion of 1-5 years (268.27).

Table 6. The mean score of teacher emotional intelligence based on the length of devotion

\begin{tabular}{lccc}
\hline Length of Devotion & $\mathrm{N}$ & Mean & Standard of Deviation \\
\hline 105 years & 55 & 268.67 & 17.54 \\
6-10 years & 202 & 278.44 & 16.25 \\
11-15 years & 164 & 276.86 & 14.47 \\
16-20 years & 128 & 278.43 & 14.53 \\
21 years or more & 51 & 271.53 & 15.70 \\
\hline
\end{tabular}

Table 7 shows that there is a significant different mean scores of the teacher emotional intelligence based on the length of devotion $(\mathrm{F} ; 4: 1471.88)=6.176)$; sig. .000).

Table 7. The results of the one-way ANOVA showing a difference in teacher emotional intelligence based on the length of devotion

\begin{tabular}{lccccc}
\hline Source & Sum of Squares & Df & Mean Square & F & Sig. \\
\hline Inter Groups & 5887.930 & 4 & 1471.982 & $6.176 .000^{* *}$ \\
In Groups & 141718.744 & 595 & 238.349 & \\
Sum & 147705.673 & 599 & & \\
\hline
\end{tabular}

*Significant at limit $p<0.05$.

**Significant at limit $p<0.01$. 


\subsection{Discussion}

The results of the analysis showed that there is no difference in the teacher emotional intelligence based on the sex with the subthemes of self-awareness, of self-management, of social awareness, and of relation management, but as a whole, there is a difference in the teacher emotional intelligence based on the sex.

It is also found that there is a significant difference in the teacher emotional intelligence based on the ages between the teachers with the age group of 25 years or more and those with the age groups of $30,35,40,50$, and of 55 years or more.

No difference is also shown in the teacher emotional intelligence based on the levels of education, namely those with certificates of S1 and S2, and is also in the subthemes of self-awareness, and of self-management. But there is a difference in the teacher emotional intelligence in the subtheme of relation management and as a whole there is a difference in the teacher emotional intelligence.

The analysis also shows that there is a difference in the teacher emotional intelligence based on the length of devotion. A significant difference is shown among the teachers with the length of devotion of 1-5 years, 6-10 years, 11-15 years and also those with the lengths of devotion of 16-20 years and of 21 years or more

The results of this present research are slightly different from those of the researches on the emotional differences between men and women. The education about emotions produces very different skills where the girls are skillful in reading signs, verbal or non verbal emotions, in expressing and communicating their emotions and boys are very smart in muffling emotions dealing with the susceptible, wrong, afraid and sick feelings (Goleman, 1999).

But Bar-On (1997) suggested that as a whole there is no significant difference in the emotional competence between male and female administrators. In other words, no difference in the emotional intelligence exists in men and women. Then Bar-On (1997) also states that there are some similarities in the emotion between men and women. And in the emotional competence, there are two teachers competences namely personal competence dealing with self-awareness and self-management, and social competence concerning with social awareness and ability to manage relations.

Don (2009) shows that there is a significant difference in the emotional competence among male than female leaders, where the emotional competence of male leaders are better than females in the sub-themes of social awareness, of self-management, and of relation management and there are differences for the subtheme of self-awareness.

According to Sala (2002) the increase in one's age will improve one's wisdom and emotional competence. It is because the maturity of one's emotional competence is through learning and experiences (Boyatzis \& Sala, 2004). According to Goleman (1998), ones' emotional intelligence improves with the age.

A research with demographic criteria with the use of ECI instrument involving 34.377 respondents and was made in 2002 to understand the emotional competence. The results showed that groups of ECI had a significant correlation with the respondents' ages (Sala, 2002). Bar-On (2000) fond that the older groups got better scores in Emotional Quotient Inventory than the young ones. Individuals with the age of last 40 s and early 50s obtained higher scores. Moreover, Bar-On (200) found that emotional intelligence improves with the ages. The same results are also obtained by Crick (2002) examining the correlation between emotional intelligence and administrative experiences among 85 students of post graduate programs in educational administration department in the university of East Tennessee. The results show that older students got higher aggregate scores in social competence and emotional intelligence.

In Latin America, Fernandez-Araoz (2001) examined 2000 executives to determine the success dealing with the length of devotion and the stage of emotional intelligence. He used IQ as the base of evaluation through interviews. Successful executives showed significant correlations with emotional intelligence, work experiences and IQ. Most of them were weak in the whole emotional intelligence.

\section{Conclusions and Suggestion}

\subsection{Conclusions}

There is a difference in the teacher emotional intelligence based on the sex with the subthemes of self-awareness and the whole. But there is no difference in teacher emotional intelligence with the subthemes of self-management, social awareness, and relation management based on the sex.

There is a significant difference in the teacher emotional intelligence based on the age, namely between the age group of 25 years or more and of 30 years or more, the age group of 35 years or more and of 40 years or more, 
and of 45 years or more and that of 5 years or more and other age groups. But there is no significant difference in the teacher emotional intelligence between the teachers with the age group of 25 years or more and of 35 years or more, and of 55 years or more and the other age groups.

There is no difference in the teacher emotional intelligence based on the levels of education between teachers with S1 degree and S2 degree in the subthemes of self-awareness, self-management, and social awareness. But there is a difference in the subtheme of relation management and the whole.

There is a difference in the teacher emotional intelligence based on the length of devotion. The differences happened to those with the length of devotion of 1-5 years and of 6-10 years, and of 11-15 years and 16-20 years and those with other groups of devotion. But there is no significant difference in the teacher emotional intelligence between those with the length of devotion of 1-5 years and of 21 years or more and the other groups of length of devotion.

\subsection{Suggestion}

The Department of Education and Art of Tangerang should try to improve teacher emotional intelligence by providing teachers with a short course on the emotional intelligence. Headmasters should improve their teachers' emotional intelligence by organizing religious activities, trainings on emotional intelligence, and any activities among teachers out of the teaching and learning activities at schools. Deliberation of Subject Teachers should be maximum in making, organizing and improving the programs and activities in order to improve teachers' emotional intelligence. Teachers should improve their emotional intelligence they have possessed personally by doing drills of emotional intelligence, joining in religious and social activities and also should try to improve self-management, self-awareness, relation management and social awareness.

Other researchers should widen researcher by involving mode samples and wider areas such as provincial or national scopes in order to produce in-depth and detailed explanations on the contribution of emotional intelligence to teacher emotional intelligence and also inferential relations between the two. Other researchers should also make qualitative researches or combine the two namely quantitative and qualitative methods.

\section{References}

Amabile, T. (1988). The intrinsic motivation principle of creativity. In B. Staw, \& L. L. Cummings (Eds.), Research in organizational behavior. Greenwich, CT: JAI Press.

Bar-On, R. (1997). Emotional quotient inventory. Technical manual. Toronto: Multi Health System.

Bar-On, R. (2000). Emotional and social intelligence: Insights from the Emotional Quotient Inventory. In R. Bar-On, \& J. Parker (Eds.), The Handbook of Emotional Intelligence: Theory, Development, Assessment, and Application at Home, School, and in the Workplace (pp. 363-388). San Francisco, California: Jossey Bass Inc.

Bougue, D. J. (1969). Pribciple Demograpy. New York: J. Wiley \& sons.

Boyatzis, R. E. (1982). The component manager, A Model for effective performance. New York: John Wiley \& Sons.

Boyatzis, R. E. (2001). Develoving Emtional Intellegince. In C. Chernis, R. Boyatzis, \& M. Elias (Eds.), Develovmnets in Emtional Intelligence (pp. 121-154). San Francisco, CA; Joss-Bass.

Boyatzis, R. E., \& Sala, F. (2004). Assessing emotional intelligence competencies. In G. Geher (Ed.), The measurement of emotional intelligence (pp. 147-186). Hauppauge, NY: Nova Science Publishers.

Boyatzis, R. E., Goleman, D., \& Rhee, K. S. (2000). Clustering competence in emotional intelligence. In R. Bar-On, \& J. D. A. Parker (Eds.), The handbook of emotional intelligence (pp. 343-362). San Francisco, CA: Jossey-Bass.

Crick, A. T. (2002). Emotional intelligence, social competence, and success in high school students (Unpublished master's thesis). Western Kentucky University, Bowling Green.

Danim, S. (2003). Menjadi komunitas pembelajar, kepemimpinan tranformasional dalam komunitas pembelajar. Jakarta: Bumi Aksara.

Don, Y. (2009). Korelasi dan pengaruh kompetensi emosi terhadap kepemimpinan sekolah: Perbandingan antara sekolah berkesan dan sekolah kurang berkesan. Thesis: Fakulti Pendidikan Universiti Malaya Kuala Lumpur. Tidak diterbitkan.

Fernandez-Araoz, C. (2001). The challenging of hiring senior executive. In C. Cherniss, \& D. Goleman (Eds.), 
The emotionally intelligent workplace. San Francisco, CA: Josey-Bass.

Gay, L. R., \& Airasin, P. (2001). Educational Research: Competencies for Analysis an Aplication (5th ed.). Upper Sadle River, NJ: Prentice Hill.

Goleman, D. (1998). Working with emotional intelligence. New York: Bantan.

Goleman, D. (2001). Emotional intelligence. Terj. T. Hermaya, Jakarta: Gramedia.

Hair, J. F. (2010). Multivariat data analysis (Edisi ke-6). New Jersey: Pearson Educational International.

Hauser, P. M., \& Duncan, O. D. (1959). Human Ecology and Population Studies. In P. M. Hauser, \& O. D. Duncan (Eds.), The Study of Population (pp. 678-716). Chicago University of Chicago Press.

Holahan, C. K., \& Sears, R. R. (1995). The gifted group in later maturity. Stanford: Stanford University Press.

Indriyuli, R. (2011). Pengertian dan Komposisi Penduduk. Retrieved from http://rinaindriyuli.wordpress.com/ 2011/12/26/pengertian-dan-komposisi-penduduk/.Diakses Januari 2013

Kerlinger, F. N. (1993). Foundation of Behavior research. New York: Holt Saunder.

Konting, M. M. (1990). Kaedah penyelidikan pendidikan. Kuala Lumpur: Dewan Bahasa dan Pustaka.

Mukhtar, \& Priambodo, E. A. (2003). Mengukir prestasi. panduan menjadi guru profesional. Jakarta: Misaka Galiza.

Mulyasa, E. (2005). Menjadi Guru Profesional Menciptakan Pembelajaran Kreatif dan Menyenangkan. Bandung: Remaja Rosdakarya.

Nunally, J. C. (1978). The study of change in evaluation research: Principles concerning measurement, experimental design and analysis. In L. S. Elmer, \& M. Gutentag, (Eds.), Handbook of evaluation Research. Beverley Hills, California: Sage.

Pallan, J. (2001). SPSS Survival manual: A Step by step guide to data analysis using SPSS. New Sydney, Australia: Allen \& Unwin.

Parker, G. M. (1990). Team players and teamwork. Sanfrancisco, CA. Jossey-Bass

Pers, L. S. (1996). Statistical analysis for educatioan and psycology Researchs. London: The Falmers Press.

Rismawari, E. (2012). Komposisi Penduduk. Retrieved from http://edelweissgreen.wordpress.com/2012/01/17/ komposisi-penduduk/

Rubbin, A., \& Babbie, E. (2001). Reserch methods for social work. Calipornia: Wasworth Brooks.

Sala, F. (2003). Leadership in education: Effective UK college principal. Nonprofit Management Leadership, 14(2), 171-189. http://dx.doi.org/10.1002/nml.28

Sekaran, V. (2003). Research Method for Bussiness (3rd edition). New Jersey: John Wiley \& Sons.

Setiawan, S. (2008). Agenda pendidikan nasional. Jogyakarta: Ar-Ruz Media.

Spencer, L. M., Jr., \& Spencer, S. M. (1993). Competence at work: Model for superior performance. New York: John Wiley \& Sons.

\section{Copyrights}

Copyright for this article is retained by the author(s), with first publication rights granted to the journal.

This is an open-access article distributed under the terms and conditions of the Creative Commons Attribution license (http://creativecommons.org/licenses/by/3.0/). 